\title{
Detection of mRNA and immunoreactive proteins for acidic and basic fibroblast growth factor and expression of the fibroblast growth factor receptors in the bovine oviduct
}

\author{
C. Gabler ${ }^{1}$, B. Lauer ${ }^{1}$, A. Einspanier ${ }^{2}$, D. Schams ${ }^{1}$ and R. Einspanier ${ }^{1 *}$ \\ 'Institute of Physiology, FML-Weihenstephan, TU München, 85350 Freising, Germany; and ${ }^{2}$ German \\ Primate Center, Dept of Reproduction, 37077 Göttingen, Germany
}

\begin{abstract}
The heparin-binding acidic and basic fibroblast growth factors (aFGF, bFGF) and their receptors in the bovine oviduct are described. By means of western blot analysis one $18 \mathrm{kDa}$ aFGF and two bFGF proteins ( 16 and $18 \mathrm{kDa}$, respectively) were detected in oviductal flushings. Different concentrations of these two growth factors could be measured in oviductal flushings during the oestrous cycle: concentrations of aFGF protein were significantly higher at ovulation (mean \pm SEM; $5.3 \pm 0.5 \mathrm{ng} \mathrm{ml}^{-1}$ ) than during the luteal phase $\left(3.0 \pm 0.3 \mathrm{ng} \mathrm{ml}^{-1}\right)$; concentrations of $b F G F$ were higher at the preovulatory stage $\left(3.5 \pm 0.7 \mathrm{ng} \mathrm{ml}^{-1}\right)$ than at the post-ovulatory stage $\left(1.3 \pm 0.15 \mathrm{ng} \mathrm{ml}^{-1}\right)$. Immunohistochemical studies using a/bFGF-specific antibodies indicated that these growth factors were localized mainly in oviduct epithelial cells. The sequence of the bovine FGF receptor (FGFR) was partly determined. Quantification of mRNAs by an RNase-protection assay (RPA) showed that expression of aFGF and bFGF was different during the oestrous cycle, indicating that the regulation of aFGF is separate from that of bFGF. Only mRNA encoding bFGF and FGFR could be detected in cumulus-oocyte complexes by reverse transcription PCR. In summary, the components of the FGF system were found in the bovine oviduct suggesting an autocrine or paracrine regulation involving oviduct cells and cumulus-oocyte complexes.
\end{abstract}

\section{Introduction}

The oviduct is responsible for providing the optimal environment for fertilization of the egg and early embryonic development. A role for oviductal growth factors in regulating proliferation and differentiation of the early embryo has been suggested (Bavister, 1988). Various growth factors (epidermal growth factor (EGF), transforming growth factor $\alpha$ (TGF- $\alpha$ ), insulin-like growth factor I (IGF-I), transforming growth factor $\beta$ (TGF- $\beta$ )) have been identified in the oviducts from some mammalian species (Lei and Rao, 1992; Chegini et al., 1994; Adachi et al., 1995; Dalton et al., 1995); but only a few growth factors have been identified in the bovine oviduct (plateletderived growth factor a (PDGFa) by Eriksen et al.,1993; IGF-I by Schmidt et al. 1994; basic fibroblast growth factor (bFGF) by Viuff et al., 1995; activin by Gandolfi et al., 1995). In addition, mRNAs encoding bFGF, TGF- $\alpha$, TGF- $\beta$, PDGFa and IGF-II have been detected in bovine oviduct epithelial cells in culture (Watson et al., 1992). These authors suggest that bFGF is present in early bovine embryos, indicating that such growth

*Correspondence.

Revised manuscript received 13 September 1996. factors could play an important role in embryogenesis. bFGF is reported to promote the formation of the mesoderm in rabbits in vitro (Hrabe de Angelis and Kirchner, 1993) as well as the transition of bovine morulae to blastocysts (Larson et al., 1992). Heparin-binding growth factors, such as aFGF and bFGF, show a similar potency in the induction of the mesoderm in Xenopus blastocysts (Slack et al., 1989).

Both fibroblast growth factors share high structural homology and are recognized by the same receptor-type (Basilico and Moscatelli, 1992). Much more is known about functional aspects of the bFGF because aFGF displays a 50-fold reduced activity (Gospodarowicz et al., 1986a, b). In addition, heparin was found to enhance the mitogenicity of aFGF, thus assigning both growth factors equal potency in cell activation (Gospodarowicz et al., 1987).

The aims of the study reported here were to characterize aFGF and bFGF proteins in bovine oviductal fluid and to assess the expression of $a / b F G F s$ and their receptors in oviduct epithelial cells throughout the oestrous cycle. The cellular localization of a/bFGF in the tissue was achieved by immunohistochemistry. Furthermore, the components of the FGF system were analysed in the cumulus-oocyte complexes with regard to possible interactions in the oviduct. 


\section{Materials and Methods}

\section{Tissue collection}

Oviducts and ovaries from German Fleckvieh cows were collected at a local abattoir within 20 min of slaughter. The stage of the oestrous cycle was defined (Ireland et al., 1980) from the appearance of the ovaries (follicles and corpora lutea) and uterus (size, colour, consistency, presence of connective tissue and mucus). The oviducts were accordingly classified into four groups: post-ovulation (days 1-5), early-mid-luteal stage (days 6-12), late luteal stage (days 13-18) and preovulatory stage (days 19-21). For RNA and protein analysis the oviducts were flushed twice with $1 \mathrm{ml}$ Ringer solution (Fresenius AG, Bad Homburg). After centrifugation at $570 \mathrm{~g}$ for $3 \mathrm{~min}$ at $4^{\circ} \mathrm{C}$, the supernatants and cell pellets were stored separately at $-80^{\circ} \mathrm{C}$.

Viability of cells was confirmed by observation under a microscope of beating cilia and by the exclusion of Trypan blue. Verification of cell type from oviductal flushings was made using the specific epithelial cell marker cytokeratin: oviduct cell pellets were spread onto microscope slides, airdried, fixed in methanol and treated with $0.9 \% \mathrm{H}_{2} \mathrm{O}_{2}$. After incubation with a monoclonal anti-pan cytokeratin antibody (clone C-11; Sigma, St Louis, MO) using a 1:600 dilution, antigen localization was achieved by a secondary biotinlabelled anti-mouse-IgG-antibody and StrepABComplex HRP (Dakopatts, Hamburg) followed by 3,3 diaminobenzidine (DAB) staining. Subsequently, cells were counterstained with haematoxylin and mounted in entellan (Merck, Darmstadt). The flushed cells were predominantly epithelial cells ( $>50 \%$ ) and are, therefore, subsequently referred to as oviduct epithelial cells.

For immunohistochemistry, the oviducts were dissected into the ampulla and the isthmus. Pieces of tissue $2 \mathrm{~cm}$ in length were mounted in Tissue Tek (Miles Inc., Elkhart, IN) and immediately stored at $-80^{\circ} \mathrm{C}$ until examined. Ovarian antral follicles $(5-10 \mathrm{~mm}$ diameter) were punctured using a $20 \mathrm{G}$ hypodermic needle and a $1 \mathrm{ml}$ syringe. Cumulus-oocyte complexes were recovered for RNA extraction from the settled follicular fluid by aspiration.

\section{Western blotting and immunohistochemistry}

The supernatants of eight oviduct flushings were pooled, diluted in equilibration buffer $\left(0.3 \mathrm{~mol} \mathrm{NaCl} \mathrm{l}{ }^{-1} ; 0.01 \mathrm{~mol}\right.$ Tris-HCl $1^{-1} ; \mathrm{pH} 7.2$ ) and applied on a heparin-Sepharose CL $6 \mathrm{~B}$ column (Pharmacia, Uppsala). Affinity chromatography was carried out as described by Schams et al. (1994). Bound material was eluted with $3 \mathrm{~mol} \mathrm{NaCl}^{-1}$ and precipitated with an equal volume of acetone at $-30^{\circ} \mathrm{C}$. After centrifugation at $10000 \mathrm{~g}$ for $10 \mathrm{~min}$ at $5^{\circ} \mathrm{C}$, proteins were dissolved and analysed by western blot using anti-aFGF and anti-bFGF antisera (rabbit polyclonal; aFGF 1:10 000; bFGF 1:30000) as described by Schams et al. (1994). Antibody-protein complexes were detected using a goat anti-rabbit IgG peroxidase conjugate (Sigma) in combination with a chemiluminescence system (ECL; Amersham, UK).

For immunohistochemistry, frozen sections of the isthmus and the ampulla $(7 \mu \mathrm{m})$ were mounted together on gelatincoated slides. The sections were fixed in cold methanol, air-dried and treated with hydrogen peroxide $\left(0.5 \% \mathrm{H}_{2} \mathrm{O}_{2}\right.$ in PBS) to reduce endogenous peroxidase activity. Sections were analysed for the presence of aFGF and bFGF by use of the same antibodies as for immunoblot analysis (respectively 1:5000). Immunoreactivity was visualized using the alkaline phosphatase technique (APAAP-complex; Dianova, Hamburg) and the conjugated avidin-biotin method (LSAB-Kit; Dakopatts) twice for both antibodies. The specificity of the staining reaction was monitored in control sections where the primary antibody had been omitted or was replaced with serum IgG. As a further control for specificity, antibodies were used that had been preabsorbed with excess aFGF and bFGF immunogen, respectively. The same cytokeratin antibody (Sigma; 1:600) as for the verification of flushed cells was used for specifically detecting epithelial cells. Sections were counterstained with Mayer's haematoxylin, mounted in glycerin jelly and examined using a Zeiss microscope. Sections were stained with methylene blue for morphological investigations.

\section{Radioimmunoassay}

Concentrations of aFGF and bFGF in oviductal flushings were determined by radioimmunoassay (Schams et al., 1994) using the same antibodies as described previously for immunoblot analysis. The intra-assay variations were between $3.5 \%$ and $6.4 \%$, and interassay values between $7.2 \%$ and $13.9 \%$. The crossreactivities of the antibodies to other growth factors (human PDGF-AB, from Saxon Biochemicals, Bachem, CA; recombinant bovine vascular endothelial growth factor (VEGF), generously provided by D. Gospodarowicz, Chiron Corp., Oakland CA; TGF- $\alpha$, from PeproTech Inc., Rocky Hill, NJ; human native TGF- $\beta$, from Saxon Biochemicals; human recombinant IGF-l from Ciba-Geigy, Basel) and of aFGF versus bFGF (both provided by $\mathrm{D}$. Gospodarowicz) and vice versa were below $0.1 \%$.

\section{Isolation of RNA}

Total RNA was isolated from oviduct epithelial cells and cumulus-oocyte complexes by the single step method of Chomczynski and Sacchi (1987) using Trizol reagent (Gibco BRL, Gaithersburg, MD). Total RNA was quantified spectroscopically at $260 \mathrm{~nm}$. Quantity and quality of oviductal RNA $(8 \mu \mathrm{g})$ was verified after electrophoresis on a $1 \%(\mathrm{w} / \mathrm{v})$ denaturing agarose gel followed by ethidium bromide staining.

\section{Reverse-transcription ( $R T)-P C R$}

Oviductal RNA (4 $\mu g)$ and RNA from cumulus-oocyte complexes $(1 \mu \mathrm{g})$ were used to generate single-strand $\mathrm{cDNA}$ in a $60 \mu \mathrm{l}$ and $30 \mu \mathrm{l}$ reaction mixture, respectively, as described by Schmidt et al. (1994). Commercially synthesized PCR primers (Pharmacia) were used to amplify specific bovine transcripts:

\section{aFGF}

forward 5'GCT GAA GGA GAA ACC ACG AC3' reverse 5'GTT TTC CTC CAA CCT TTC CA $3^{\prime}$ bFGF

forward 5'GAA CGG GGG CTT CTT CCT3' reverse 5'CCC AGT TCG TTT CAG TGC C3' 
FGFR (following Xin et al., 1994)

forward 5'GAR ATG GAG RTG ATG AAG MTG ATY GG3'

reverse $5^{\prime}$ CCC RAA RGA CCA SAC RTC ACT CTG3'

Ubiquitin (Ubq)

forward 5'ATG CAG ATC TTT GTG AAG AC3'

reverse: $5^{\prime}$ CTT CTG GAT GTT GTA TC3'

The predicted sizes of the RT-PCR products were $317 \mathrm{bp}$ for aFGF, $288 \mathrm{bp}$ for bFGF, $471 \mathrm{bp}$ for FGFR and $189 \mathrm{bp}$ for Ubq. For each cycle phase and cumulus-oocyte complex, four independent PCR reactions were carried out.

PCR reaction mixtures contained $5 \mu \mathrm{l}$ cDNA, $1.5 \mathrm{mmol}$ $\mathrm{MgCl}_{2} \mathrm{l}^{-1}, 50 \mathrm{mmol} \mathrm{KCl}{ }^{-1}, 10 \mathrm{mmol}$ Tris- $\mathrm{HCll}^{-1}(\mathrm{pH} \mathrm{8.8)}$, $0.12 \mathrm{mmol} d \mathrm{dNPs}^{-1}, 0.4 \mu \mathrm{mol}$ of each primer and 0.5 units of heat-stable DNA polymerase (Primezyme; Biometra, Göttingen) in a final volume of $25 \mu \mathrm{l}$. Individual amplification programmes were applied for aFGF and FGFR ( 32 cycles at $94^{\circ} \mathrm{C}$ and $60^{\circ} \mathrm{C}$, I min each), bFGF $\left(30\right.$ cycles at $94^{\circ} \mathrm{C}$ and $55^{\circ} \mathrm{C}$, 1 min each), ubiquitin $\left(20\right.$ cycles at $94^{\circ} \mathrm{C}, 55^{\circ} \mathrm{C}$ and $72^{\circ} \mathrm{C}, 45 \mathrm{~s}$ each). Subsequently, $5 \mu$ l PCR product was subjected to $1.5 \%$ agarose gel electrophoresis followed by ethidium bromide staining. Specificity of RT-PCR products was verified after subcloning by double-stranded DNA-sequencing (Sequiserve; Vaterstetten).

\section{Ribonuclease protection assay (RPA)}

The a/bFGF and FGFR cDNA derived from RT-PCR was ligated into the pCR-Script ${ }^{(m)} \mathrm{SK}(+)$ cloning vector (Stratagene, La Jolla, CA). Specific clones were transcribed with RNA polymerase (Stratagene) to generate 400 base, 350 base and 544 base antisense RNA probes, respectively, labelled with $\left[\alpha{ }^{32} \mathrm{P}\right] \mathrm{CTP}$ (800 Ci mmol $]^{-1}$; Amersham, Amersham, Bucks) as described in the instructions of the RNA transcription kit (Stratagene). Labelled antisense RNAs were purified using microSpin ${ }^{\left({ }^{\prime}\right.}$ columns (Pharmacia). The ribonuclease protection assay was performed using the RPA II kit (Ambion, Austin, CA) introducing $30 \mu \mathrm{g}$ (for aFGF and FGFR) and $20 \mu \mathrm{g}$ (for bFGF) oviduct epithelial cell RNA ( $n=8$ for each stage) hybridized to $4.0 \times 10^{4}$ c.p.m. of ${ }^{32} \mathrm{P}$-labelled antisense a/bFGF or FGFR RNA. After $18 \mathrm{~h}$ hybridization, RNase digestion buffer (aFGF: $1.25 \mathrm{U} \mathrm{ml}^{-1}$ RNase $A$ and $50 \mathrm{U} \mathrm{ml}^{-1}$ RNase TI; bFGF and FGFR: $2.5 \mathrm{U} \mathrm{ml}^{-1}$ RNase $A$ and $100 \mathrm{U} \mathrm{ml}^{-1}$ RNase T1) were added to each sample. Protected probes were detected by horizontal electrophoresis on a denaturing $15 \%$ Cleangel (Pharmacia) as described by Plath et al. (1996). The resultant band signal intensities were scanned by the Pharmacia Video Doc System and subsequently analysed with the Image Master ID-program (Pharmacia).

\section{Statistical analyses}

All data from radioimmunoassays and ribonuclease protection assays were analysed by ANOVA. When ANOVA showed significant differences, the Bonferroni test (Snedecor and Cochran, 1982) was used to test significance. The data analysed were normally distributed as tested by the Kolmogorow-Smirnov method. (a)

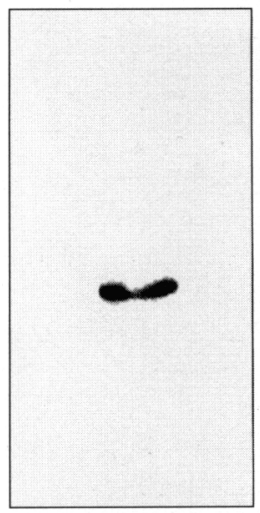

(b)

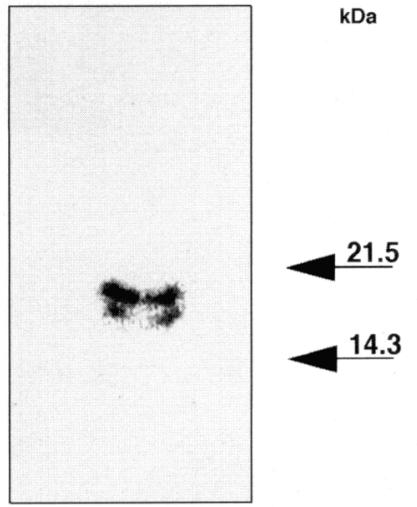

Fig. 1. Western blot analysis of heparin-binding growth factors in pooled flushings from bovine oviducts $(n=8)$ after heparin-affinity chromatography. Specific antiserum was used to detect (a) acidic fibroblast growth factor and (b) basic fibroblast growth factor.

\section{Results}

The heparin-binding growth factors aFGF and bFGF were immunologically identified in bovine oviductal fluid. After size separation of heparin-enriched oviductal fluid proteins, a single aFGF species was detected at about $18 \mathrm{kDa}$ (Fig. Ia). However, two bFGFs, representing a main band at $18 \mathrm{kDa}$ and a minor one at $16 \mathrm{kDa}$, were identified (Fig. $1 \mathrm{~b}$ ). The specificity of this reaction was verified by competition using native $a / b F G F$ proteins.

Immunohistochemical analysis showed specific labelling for aFGF and bFGF on the epithelial surface of bovine oviducts (Fig. 2). Only weak signals could be detected in the cytoplasm of epithelial cells. Additional immunostaining, at the basal membrane and in vascular cells of blood capillaries, was observed for bFGF. There were no marked differences in the intensity of staining between samples from the luteal and follicular phase or between samples from the ampulla and isthmus regions.

Mean concentrations of soluble aFGF and bFGF proteins in oviductal flushings as measured by radioimmunoassay were as follows: aFGF content was high around ovulation (mean \pm SEM: $\left.5.3 \pm 0.5 \mathrm{ng} \mathrm{ml}^{-1}\right)$ and decreased significantly $(P<0.05)$ thereafter during the early luteal phase $\left(3.1 \pm 0.3 \mathrm{ng} \mathrm{ml}^{-1}\right)$. A continuous increase of aFGF at the late luteal phase $\left(3.5 \pm 0.5 \mathrm{ng} \mathrm{ml}^{-1}\right)$ until the preovulatory stage at days $19-21$ ( $4.6 \pm 0.5 \mathrm{ng} \mathrm{ml}^{-1}$ ) was observed. Average concentrations of bFGF (1.3-3.5 $\mathrm{ng} \mathrm{m}^{-1}$ ) were lower when compared with aFGF concentration $\left(3.1-5.3 \mathrm{ng} \mathrm{ml}^{-1}\right)$. After ovulation $\left(1.3 \pm 0.15 \mathrm{ng} \mathrm{ml}^{-1}\right)$ and during the early $\left(2.4 \pm 0.2 \mathrm{ng} \mathrm{ml}^{-1}\right)$ and the late luteal phase $\left(1.7 \pm 0.15 \mathrm{ng} \mathrm{ml}^{-1}\right)$ bFGF concentrations in oviductal fluid were more stable; significantly $(P<0.05$ for days $19-21$ versus days $1-5$, and days $13-18$ versus days 19-21) increased contents were found only during the preovulatory stage $\left(3.5 \pm 0.7 \mathrm{ng} \mathrm{ml}^{-1}\right)$. However, $\mathrm{a} / \mathrm{bFGF}$ protein concentrations in extracts derived from flushed oviduct epithelial cells were very low $(<0.2 \mathrm{ng}$ per $100 \mathrm{mg}$ wet tissue) when compared with concentrations in oviductal fluid. 


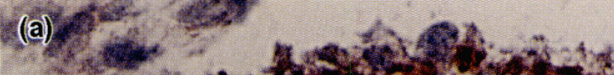

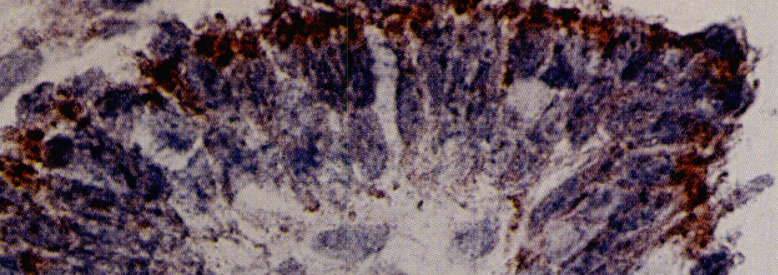

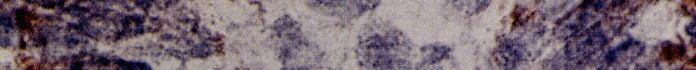

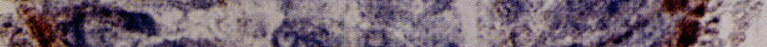

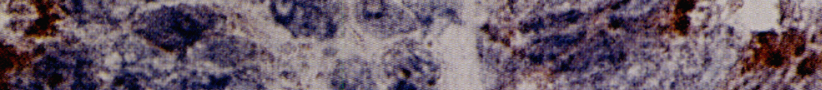

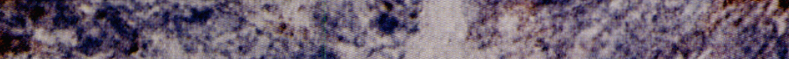

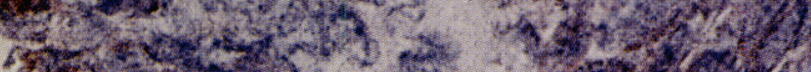

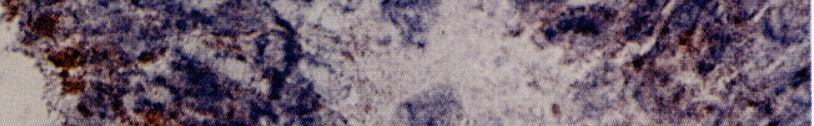

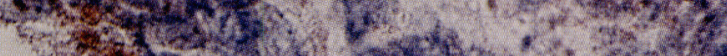
Fin $x^{2}$.

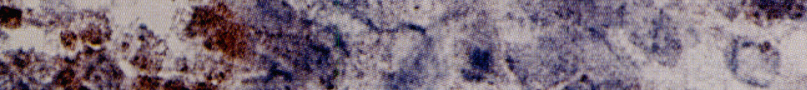

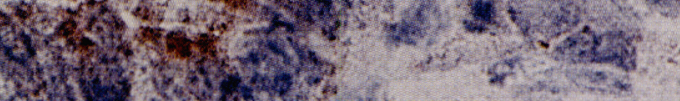

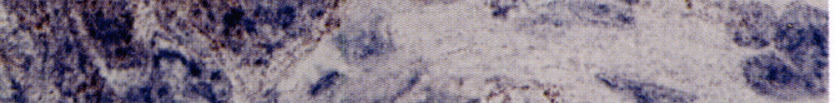

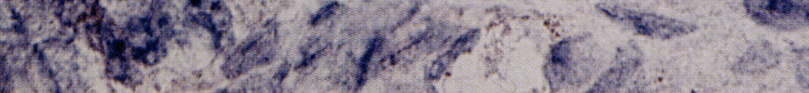

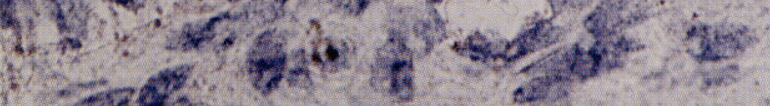

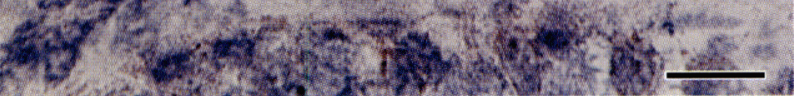

(ब)

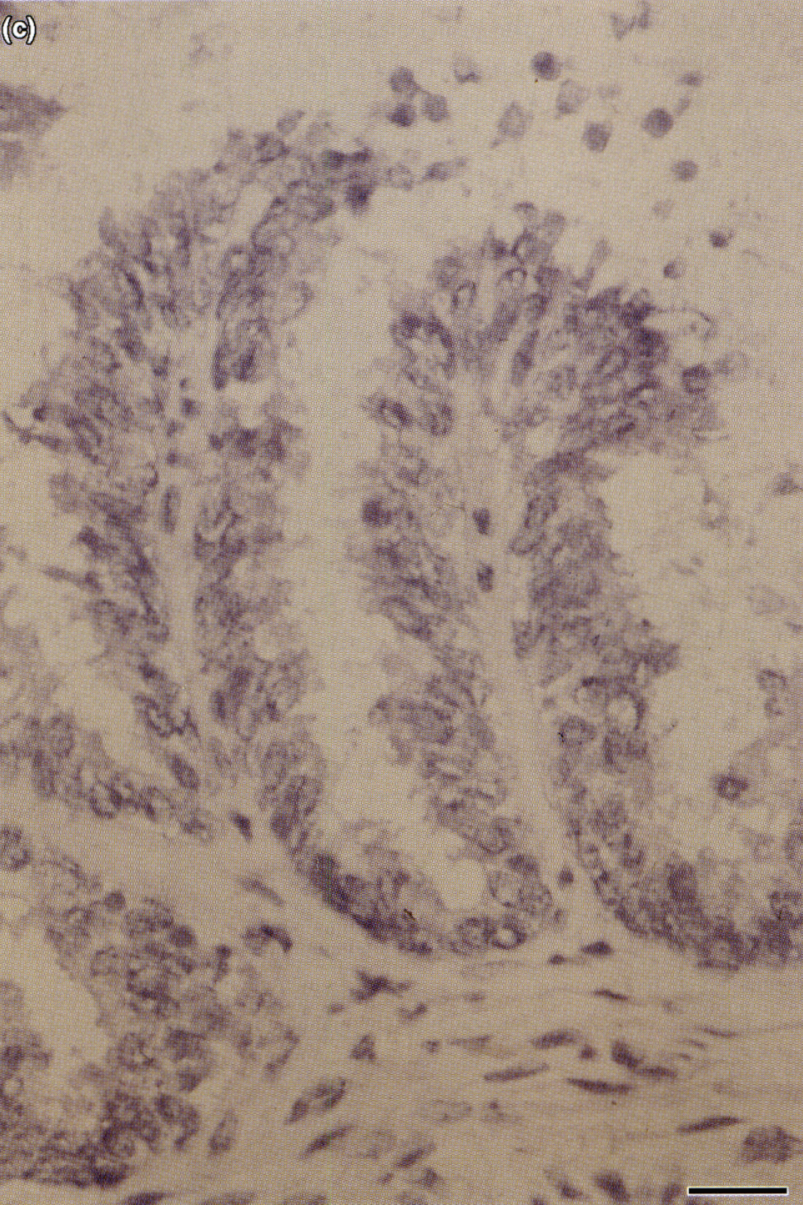

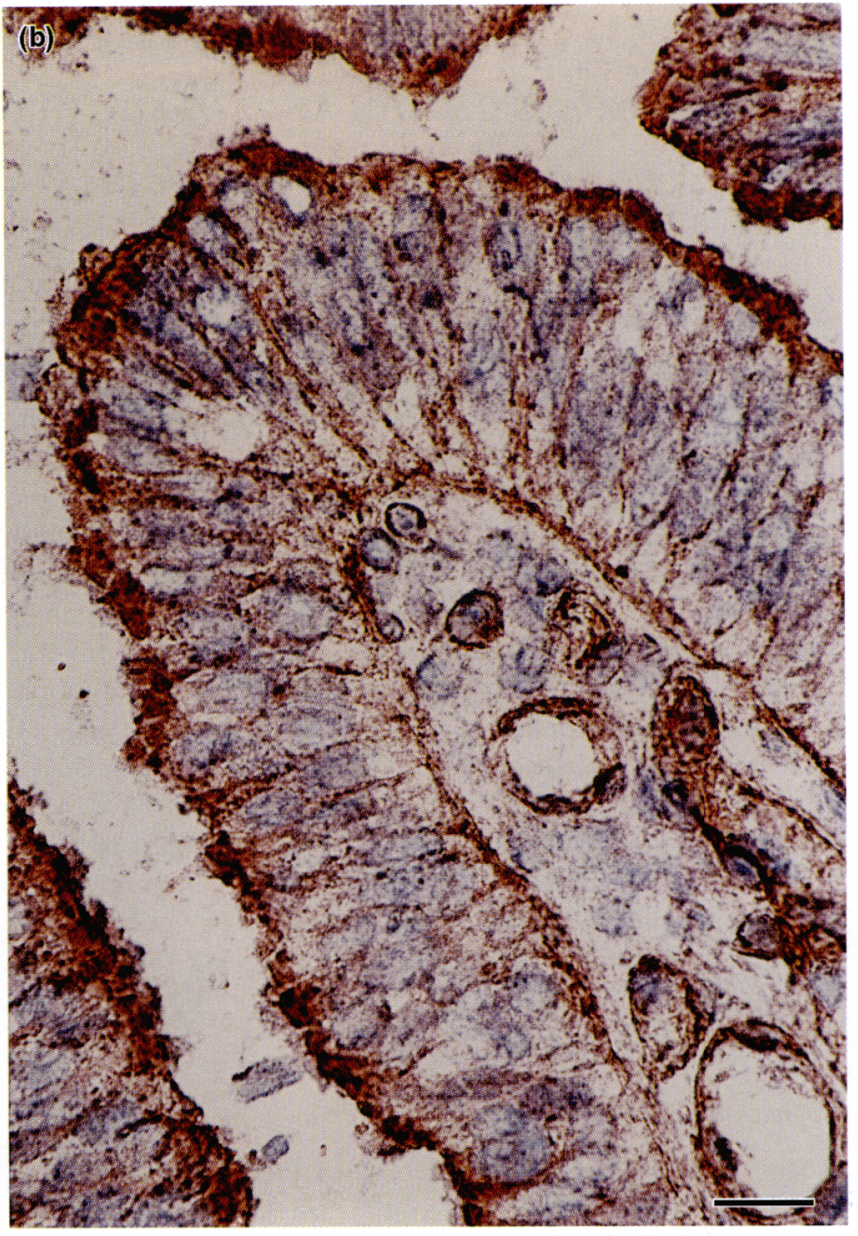

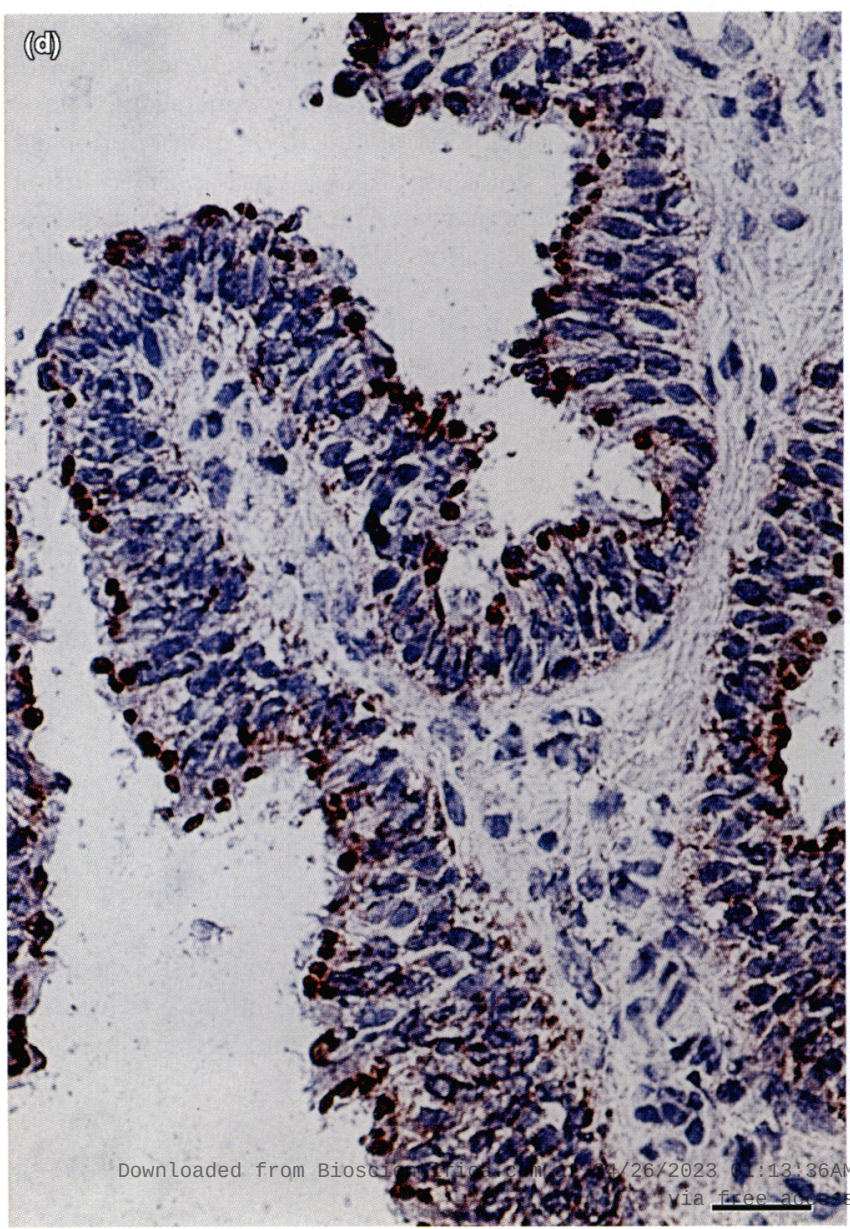




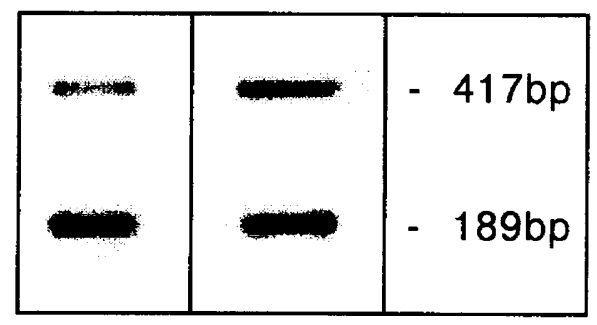

Ubq

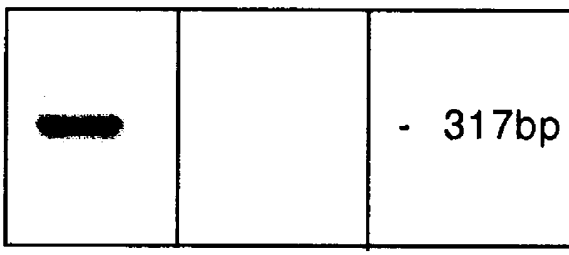

aFGF

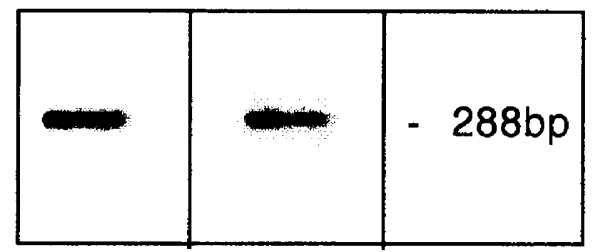

bFGF

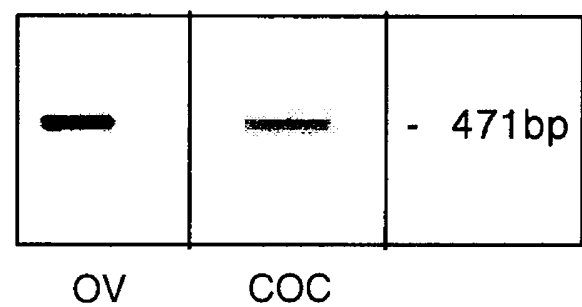

FGFR

Fig. 3. Specific reverse transcription-PCR products for ubiquitin (189 bp and $417 \mathrm{bp}$ ), acidic fibroblast growth factor (aFGF) (317 bp), basic FGF (bFGF) (288 bp) and FGF receptor (FGFR) ( $471 \mathrm{bp}$ ) separated by agarose gel electrophoresis. One representative result out of eight experiments is shown. OV: bovine oviduct epithelial cells; COC: oocyte-cumulus complexes.

Specific mRNAs encoding a/bFGF were detected in bovine oviduct epithelial cells by use of RT-PCR. Synthesis of the 'housekeeping' gene ubiquitin served as a control for the quantity and quality of mRNA. A $317 \mathrm{bp}$ aFGF-specific and a $288 \mathrm{bp}$ bFGF-specific DNA fragment were amplified from pooled bovine oviduct RNA (Fig. 3). In cumulus-oocyte complexes only signals for bFGF were found. The two ubiquitin-specific products ( 189 and $417 \mathrm{bp}$ ) verify the quality of the oviductal mRNA.

On the basis of highly homologous PCR primers, a fragment of the bovine mRNA encoding FGFR, representing part of the tyrosine kinase region of the mature receptor, was amplified. After subcloning, a partial cDNA sequence for the bovine FGFR was determined. This $471 \mathrm{bp}$ bovine cDNA sequence (EMBL-Acc.nr. Z68150) shares 90\% homology (Fig. 4) with the known human gene (EMBL-Acc.nr. M37715). The presence of the mRNA encoding FGFR was confirmed using RT-PCR for the first time in bovine oviduct epithelial cells and COC (Fig. 3).

The exact expression pattern of a/bFGF and FGFR in oviducts during different stages of the oestrous cycle was determined by assessing the mRNA content by ribonuclease protection assay. Standardized cRNAs were introduced and the following mean amounts per $\mu \mathrm{g}$ total RNA for the different mRNA species were found in flushed oviduct epithelial cells: 50 pg mRNA encoding ubiquitin, <I pg mRNA encoding aFGF, <I pg mRNA encoding bFGF and < 5 pg mRNA encoding FGFR. For aFGF, a protected signal of 317 bases was detected in all stages of the oestrous cycle. The amount of mRNA encoding aFGF was low in oviduct epithelial cells after ovulation (days $1-5$ ), but increased threefold during the luteal phase (Fig. 5a). ANOVA showed a significant difference $(P=0.0411)$, but the Bonferroni test showed no significance $(P>0.05)$ between the columns. Expression appeared to be stable for bFGF during all stages of the bovine cycle, providing a protected fragment at 288 bases (Fig. 5b). The signal intensities of the protected mRNA fragment encoding FGFR at 471 bases showed no significant variation throughout the oestrous cycle (Fig. 5c).

\section{Discussion}

The presence of the two heparin-binding growth factors, aFGF and bFGF, was verified using immunological techniques in bovine oviductal fluid as well as in oviduct epithelial cells. The size of the aFGF corresponds to the known 154 amino acid polypeptide (Burgess et al., 1985 and 1986; Crabb et al., 1986). Two molecular mass forms of bFGF were observed; a higher molecular mass form corresponding to the $18 \mathrm{kDa}$ factor and a lower molecular mass form corresponding to a known truncated $16 \mathrm{kDa}$ protein. Western blot analysis of extracts from bovine corpora lutea also showed two forms of bFGF (Schams et al., 1994). Gospodarowicz et al. (1985) demonstrated that the truncated form represents a protein with 15 amino acids fewer than the regular form. Both forms are presumed to be biologically active, although the $16 \mathrm{kDa}$ form shows an extended half life of approximately $8 \mathrm{~h}$ (Moscatelli, 1988). Specific immunostaining of $a / b F G F$ on the epithelial surface of the oviduct showed that these growth factors are located towards the lumen of the oviduct. It seems likely that both factors are tightly bound to the cell surface, preferentially to heparin-glycoproteins (Einspanier et al., 1996). In contrast to aFGF, immunoreactive bFGF was also found on the basal membranes and endothelial cells of capillaries; thus, import from the blood circulation cannot be excluded. This apparent differential localization might be due to the distinct bFGF molecules known to be associated with either endothelial or epithelial bovine cells (Schams et al., 1994).

A second difference between aFGF and bFGF proteins was evident when the concentrations of the soluble FGFs in the

Fig. 2. Immunohistochemical localization of (a) acidic fibroblast growth factor, (b) basic fibroblast growth factor and (d) cytokeratin, in the bovine oviducts (mid-luteal phase, ampulla). Positive staining appears red. Cell nuclei are stained blue. (c) Negative control with pure rabbit immunoglobulin. Scale bars represent $12.6 \mu \mathrm{m}(\mathrm{a}, \mathrm{b})$ and $20 \mu \mathrm{m}(\mathrm{c}, \mathrm{d})$. 


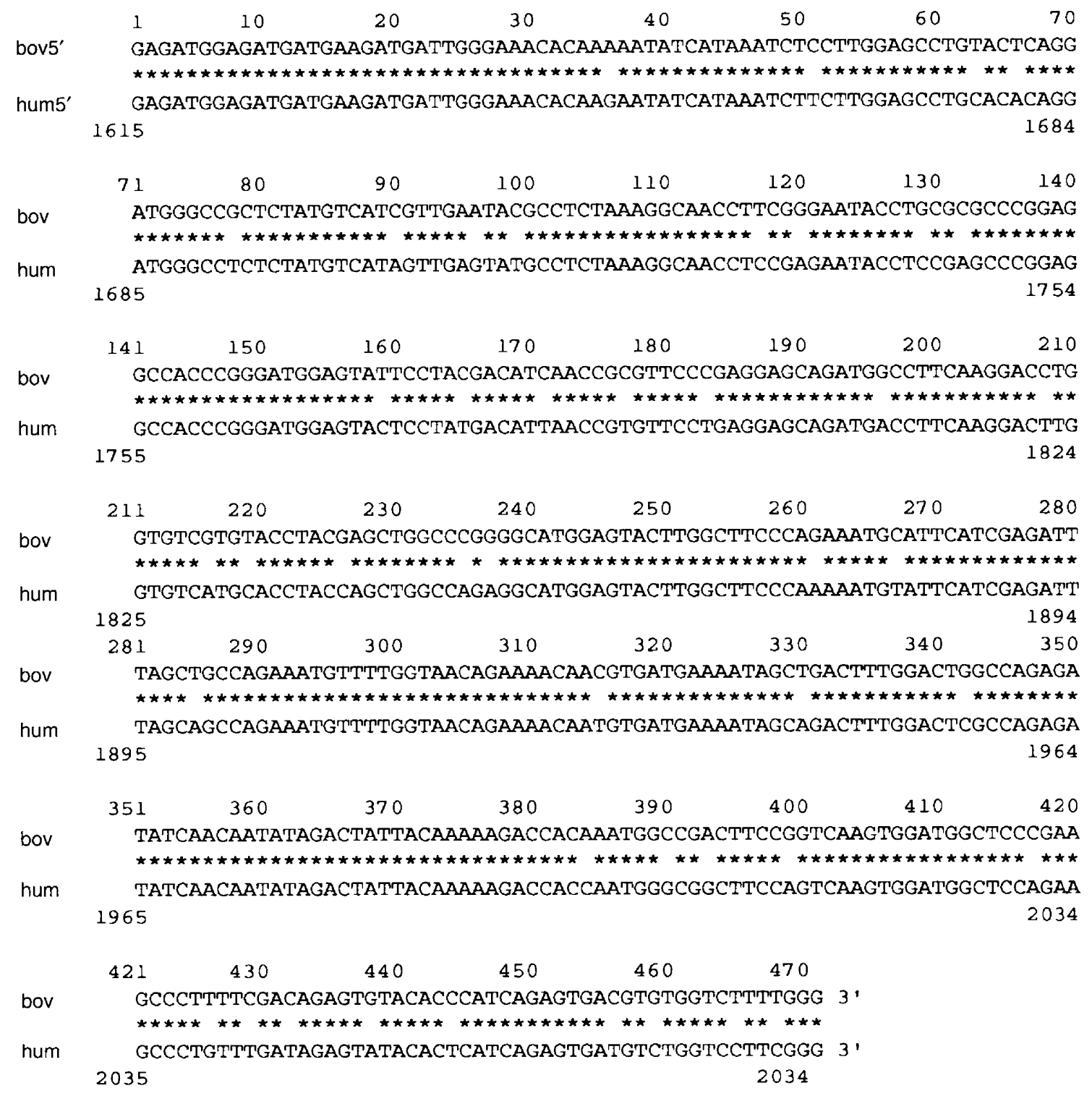

Fig. 4. Comparison of partial sequences of cDNA for the receptor for bovine (EMBL Acc.nr: Z68150) and human (EMBL Acc.nr: M37715) fibroblast growth factor showing 90\% homology. Asterisks indicate homologous bases.

oviduct were compared during the oestrous cycle: more aFGF protein appeared to be secreted into the oviduct during the postovulatory stage. In contrast, the highest bFGF concentrations were present at the preovulatory stage. Furthermore, absolute concentrations of aFGF were higher when compared with bFGF. The measured soluble FGF concentrations are sufficient to induce an effect in cells in vivo. Much lower concentrations (pg bFGF ml ${ }^{-1}$ ) can activate mesoderm development of embryos (Kimelman et al., 1988). bFGF in the mammalian oviduct could act as a stimulus for embryonic differentiation. Distinct patterns of expression have been previously observed for other proteins, indicating that the secretory activities of the bovine oviduct are oestrous cycledependent (Geisert et al., 1987; Malayer et al., 1988). However, other factors, such as heparin sulfate or extracellular matrix components, should also be considered as potential triggers of the biological activity of the FGFs.
By use of two specific mRNA detection methods (RT-PCR and RPA) it was shown that FGFs are synthesized locally in oviduct epithelial cells and that they probably do not derive from the circulation. The de novo synthesis of these proteins in oviduct epithelial cells is supported by a recently published report localizing the mRNA encoding bFGF in the bovine oviduct (Viuff et al., 1995). It is evident from a comparison of the expression patterns for aFGF and bFGF genes that these mRNAs are differentially regulated in the bovine oviduct. A siginificant decrease of aFGF expression around ovulation contrasts with that of other growth factors like IGF-I that show higher expression around ovulation, but lower expression during the luteal phase in cows (Schmidt et al., 1994). These findings suggest that, in the bovine oviduct, growth factors can act in different ways. It is of interest that the concentration of mRNA encoding aFGF is high while its soluble protein remains low, and that the expression for mRNA encoding bFGF 
(a)

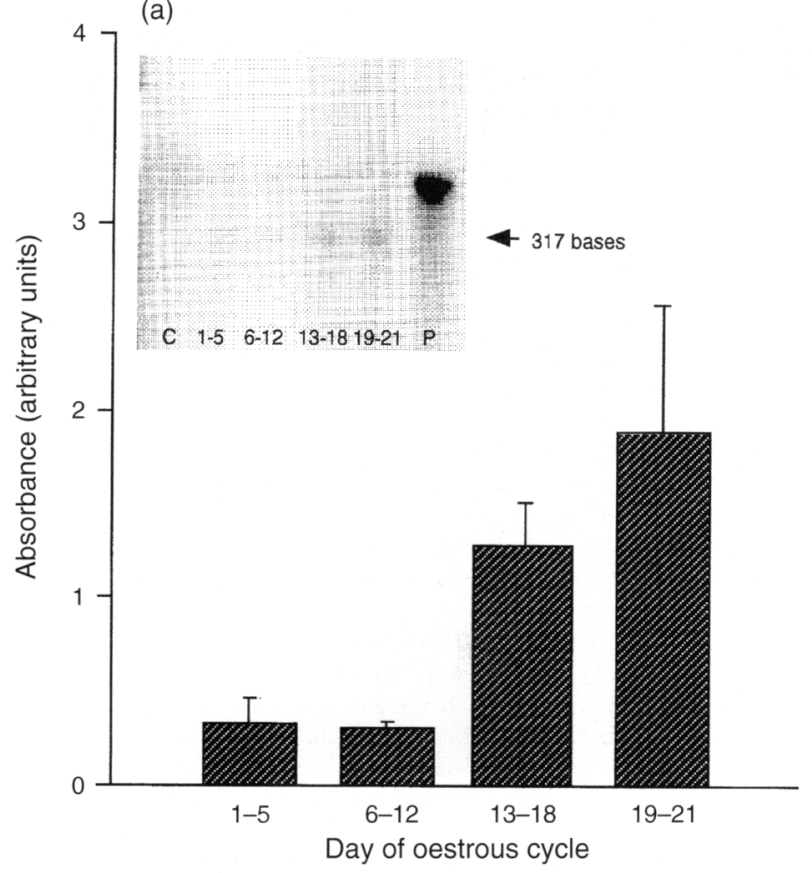

(b)

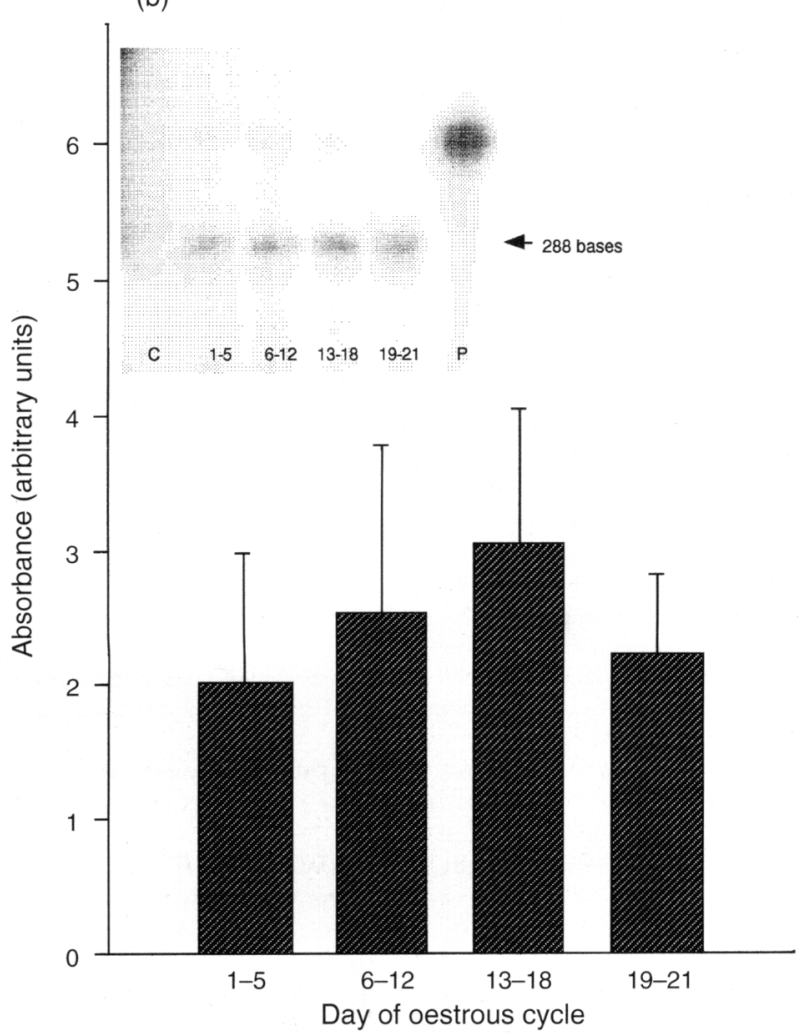

remains constant even when corresponding protein increased. A delay between the synthesis of mRNA encoding FGF and secretion of the protein could account for the effects observed. This delay could be due to intracellular processing and storage or to a strong association of $\mathrm{a} / \mathrm{bFGF}$ to heparin and heparin sulfate glycoproteins on the surface of oviductal cells iConn (c)

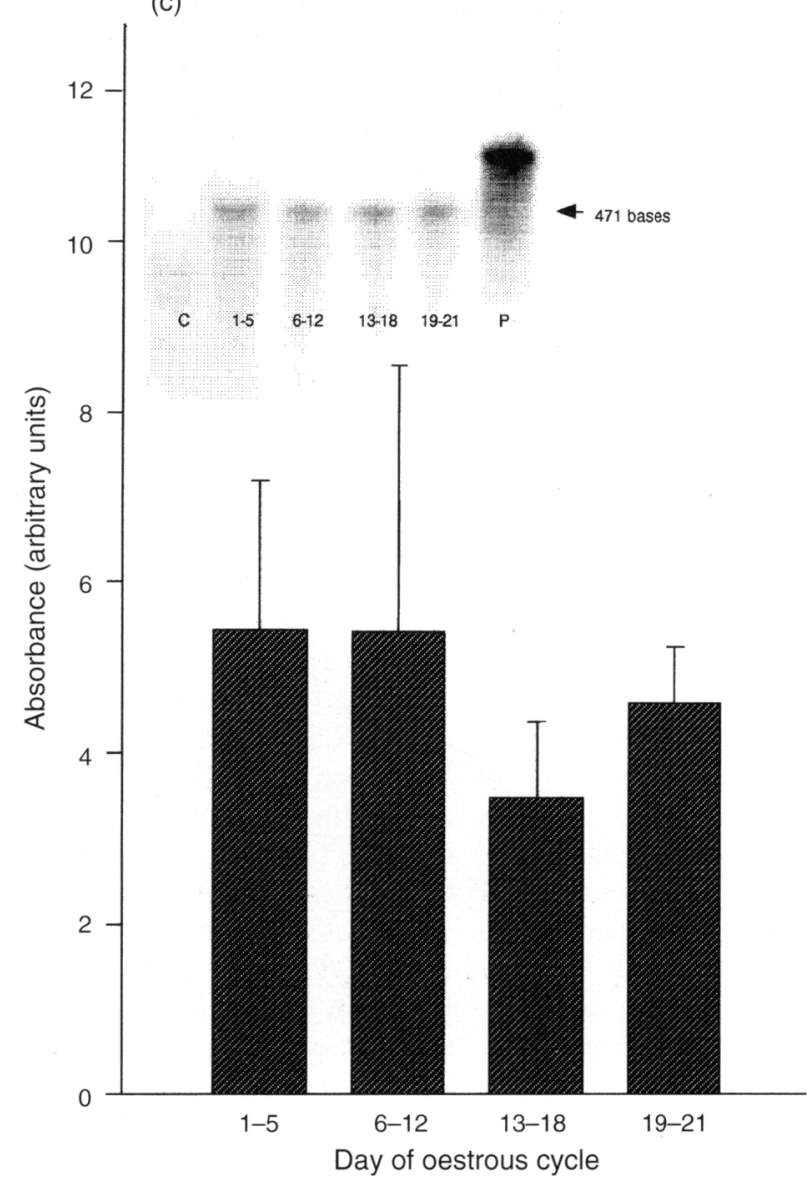

Fig. 5. Ribonuclease protection assay (RPA) using ${ }^{32}$ P-labelled antisense RNA probes showing the mRNA specific for (a) acidic fibroblast growth factor (aFGF) (b) basic FGF, and (c) FGF receptor in oviduct epithelial cells. Inserts show one representative gel out of eight (C: control with yeast RNA; P: undigested cRNA-probe). The corresponding integrated absorbance (mean \pm SEM; $n=8$ ) is depicted.

and Hatcher, 1984; Lobb and Fett, 1984; Maciag of al., 1984; Saksela ef al., 1988; Bashkin et al., 1989). The physiological reasons for an increased release of aFGF after ovulation and of bFGF in the preovulatory stage are still obscure. Furthermore, it is difficult to be accurate about the stage of the oestrous cycle when using material obtained from abattoirs. It was for this 
reason that a broader period was chosen (each measuring point covers about 5 days of the cycle) when measuring the expression of the FGFs and FGFR.

Both growth factors are recognized by the same receptor type (four subtypes are known). In the present study, a cDNA fragment for the bovine FGFR that was highly homologous to all four human receptor subtypes was detected, and its expression shown in bovine oviduct epithelial cells, indicating an autocrine or paracrine mechanism within the oviduct epithelial cells themselves. In addition, it has been suggested that these growth factors have a role in the early development of the embryo (Schultz and Heyner, 1993). Our results show that part of the FGF system is present in the cumulus-oocyte complexes. The mRNAs encoding bFGF and FGFR are expressed in lower concentrations. Although mRNA encoding aFGF has been found in bovine ovarian granulosa cells $(\mathrm{M}$. Kamhuber, D. Schams and R. Einspanier, unpublished), this could not be confirmed for the cumulus-oocyte complexes, suggesting that cumulus cells may have properties different from those of normal granulosa cells. Specific mRNAs for a/bFGF have been found in Xenopus oocytes (Kimelman et al., 1988; Shiurba et al., 1991) but it is uncertain whether these mRNAs are translated. We suggest that a/bFGF in oviductal secretion interacts with the cumulus-oocyte complexes en route to fertilization. Furthermore, it is unlikely that bFGF has an effect on the early bovine embryo until the eight-cell stage (Watson et al., 1992). Recently, two kinds of FGFR have been found in Xenopus blastulae (Gillespie et al., 1989). Thus aFGF and bFGF could act as potent mitogens on cumulus cells and thereby regulate differentiation of the early embryo.

The results of the present study support the concept that important growth factors such as a/bFGF are produced by oviduct cells and that this FGF system could act in an autocrine or paracrine manner in the bovine oviduct itself and may contribute to the optimal environment for fertilization and development of the embryo.

The authors thank A. Zuber, G. Schwentker and A. Jurdzinskie for their technical assistance and $R$. Ivell for critical reading of the manuscript. This work was supported by the DFG (Ei 296/4-I).

\section{References}

Adachi K, Kurachi H, Homma H, Adachi H, Imai T, Sakata M, Higashiguchi O, Yamaguchi M, Morishige K, Sakoyama Y and Miyake-A (1995) Estrogen induces epidermal growth factor (EGF) receptor and its ligands in human Fallopian tube: involvement of EGF but not transforming growth factoralpha in estrogen-induced tubal cell growth in vitro. Endocrinology 136 2110-2119

Bashkin P, Doctrow S, Klagsbrun M, Svah CM, Folkman J and Vlodavsky I (1989) Basic fibroblast growth factor binds to subendothelial extracellular matrix and is released by heparitinase and heparin-like molecules Biochemistry $\mathbf{2 8}$ $1737-1734$

Basilico C and Moscatelli D (1992) The FGF family of growth factors and oncogenes Advances in Cancer Research 59 115-165

Bavister BD (1988) Role of oviductal secretions in embryonic growth in vivo and in vitro. Theriogenology 29 143-154

Burgess WH, Mehlman T, Friesel R, Johnson VW and Maciag T (1985) Multiple forms of endothelial cell growth factor. Rapid isolation and biological and chemical characterization Journal of Biological Chemistry 26011 389-11 392

Burgess WH, Mehlman T, Marshak DR and Fraser BA (1986) Structural evidence that endothelial cell growth factor-beta is the precursor of both endothelial cell growth factor-alpha and acidic fibroblast growth factor Proceedings National Academy of Sciences USA 83 7216-7220

Chegini N, Zhao Y and McLean FW I (1994) Expression of messenger ribonucleic acid and presence of immunoreactive proteins for epidermal growth factor (EGF), transforming growth factor alpha (TGF alpha) and EGF/TGF alpha receptors and I25I-EGF binding sites in human Fallopian tube Biology of Reproduction 50 1049-1058

Chomczynski $P$ and Sacchi N (1987) Single-step method of RNA isolation by acid guanidinium thiocyanate-phenol-chloroform extraction Analytical Biochemistry 162 156-159

Conn G and Hatcher VB (1984) The isolation and purification of two anionic endothelial cell growth factors from human brain Biochemical and Biophysical Research Communications 124 262-268

Crabb JW, Armes LG, Carr SA, Johnson CM, Robert GD, Bordoli RS and McKeehan WL (1986) Complete primary structure of prostatropin, a prostate epithelial cell growth factor Biochemistry 25 4988-4993

Dalton T, Kover K, Dey SK and Andrews GK (1995) Analysis of the expression of growth factor, interleukin-1, and lactoferrin genes and the distribution of inflammatory leukocytes in the preimplantation mouse oviduct Biology of Reproduction 51 597-606

Einspanier R, Gabler C and Lauer B (1996) Expression of urokinase plasminogen activator (uPA) is correlated with soluble heparin-analogues and basic fibroblast growth factor (bFGF) in bovine oviducts during oestrous cycle Journal of Reproduction and Fertility Abstract Series 17 Abstract 26

Eriksen E, Terkelsen O, Hyttel P. Mollegard K and Greve T (1993) Regional morphology and localization of PDGF in bovine epithelium Theriogenology 39215

Gandolfi F, Modina S, Brevini TA, Passoni L, Artini P, Petraglia F and Lauria A (1995) Activin beta A subunit is expressed in bovine oviduct Molecular Reproduction Development 40 286-291

Geisert RD, Buhi WC and Fields M (1987) Synthesis and release of polypeptides by bovine oviductal tissue in culture Biology of Reproduction 36 Supplement 1,4

Gillespie LL, Paterno GD and Slack JM (1989) Analysis of competence: receptors for fibroblast growth factor in early Xenopus embryos Development 106 203-208

Gospodarowicz D, Cheng J, Lui GM, Baird A, Esch F and Bohlen P (1985) Corpus luteum factor is related to fibroblast growth factor Endocrinology 117 2283-2291

Gospodarowicz D, Neufeld G and Schweigerer L (1986a) Fibroblast growth factor Molecular and Cellular Endocrinology 46 187-206

Gospodarowicz D, Neufeld G and Schweigerer L (1986b) Molecular and biological characterization of fibroblast growth factor: an angiogenic factor which also controls the proliferation and differentiation of mesoderm and neuroectoderm derived cells Cell Differentiation 19 1-17

Gospodarowicz D, Ferrara N, Schweigerer L and Neufeld G (1987) Structural characterization and biological functions of fibroblast growth factor Endocrine Reviews 8 95-114

Hrabe de Angelis M and Kirchner C (1993) Fibroblast growth factor induces primitive streak formation in rabbit pre-implantation embryos in vitro. Anatomy and Embryology 187 269-273

Ireland JJ, Murphee RI and Coulson PB (1980) Accuracy of predicting stages of bovine estrous cycle by gross appearance of the corpus luteum Journal of Dairy Science 63 155-160

Kimelman D, Abraham JA, Haaparanta T, Palisi TM and Kirschner MW (1988) The presence of fibroblast growth factor in the frog egg: its role as a natural mesoderm inducer Science 242 1053-1056

Larson RC, Ignotz GG and Currie WB (1992) Transforming growth factor $\beta$ and basic fibroblast growth factor synergistically promote early bovine embryo development during the fourth cell cycle Molecular Reproduction and Development 33 432-435

Lei ZM and Rao CV (1992) Expression of epidermal growth factor (EGF) receptor and its ligands, EGF and transforming growth factor-alpha, in human Fallopian tubes Endocrinology 131 947-957

Lobb RR and Fett JW (1984) Purification of two distinct growth factors from bovine neural tissue by heparin affinity chromatography Biochemistry 23 6295-6299

Maciag T, Mehlman T, Friesel R and Schreiber AB (1984) Heparin binds endothelial cell growth factor, the principal endothelial cell mitogen in bovine brain Science $225932-935$

Malayer JR, Hansen PJ and Buhi WC (1988) Secretion of proteins by cultured bovine oviducts collected from estrus through early diestrus Journal of Experimental Zoology 248 345-353 
Moscatelli D (1988) Metabolism of receptor-bound and matrix-bound basic fibroblast growth factor by bovine capillary endothelial cells journal of Cell Biology 107 753-759

Plath A, Peters F and Einspanier R (1996) Detection and quantitation of specific mRNAs by ribonuclease protection assay using denaturing horizontal PAGE: a radioactive and non-radioactive approach Electrophoresis 17 471472

Saksela O, Moscatelli D, Sommer A and Rifkin DB (1988) Endothelial cellderived heparan sulfate binds basic fibroblast growth factor and protects it from degradation Journal of Cell Biology 107 743-751

Schams D, Amselgruber W, Einspanier R, Sinowatz F and Gosporarowitz D (1994) Localization and tissue concentration of basic fibroblast growth factor in the bovine corpus luteum Endocrine 2 907-912

Schmidt A, Einspanier R, Amselgruber W, Sinowatz F and Schams D (1994) Expression of insulin-like growth factor 1 (IGF-1) in the bovine oviduct during the oestrous cycle Experimental and Clinical Endocrinology 102 364-369

Schultz GA and Heyner S (1993) Growth factors in preimplantation mammalian embryos Oxford Reviews of Reproductive Biology 1566
Shiurba RA, Jing N, Sakakura T and Godsave SF (1991) Nuclear translocation of fibroblast growth factor during Xenopus mesoderm induction Development $113487-493$

Slack JMW, Darlington BG, Gillespie LL, Godsave SF, Isaacs HV and Paterno GD (1989) The role of fibroblast growth factor in early Xenopus development Development 107 (Supplement) 141-148

Snedecor GW and Cochran WG (1982) Statistical Methods 8th edn p 503, lowa State University Press, Ames

Viuff D, Hyttel P, Greve T, Eriksen T and Alexandersen S (1995) Transcription and localization of growth factor mRNA in the bovine oviduct Molecular Reproduction and Development 42 28-34

Watson AJ, Hogan A, Hahnel A and Wiemer KE (1992) Expression of growth factor ligand and receptor genes in the preimplation bovine embryo Molecular Reproduction and Development 31 87-95

Xin X, Johnson AD, Scott-Burden T, Engler D and Cascells W (1994) The predominant form of fibroblast growth factor receptor expressed by proliferating human aterial smooth muscle cells in culture is type I Biochemical and Biophysical Research Communications 204 557-564 